\title{
Family Class Immigration: Implications for Post-Multiculturalism
}

\author{
Edward Opoku-Dapaah and Michael Lanphier
}

\begin{abstract}
This paper examines the implications of post-multiculturalism for family class immigration to Canada. The authors argue that the goal of facilitating family reunification is not facilitated by Canadian immigration policy. A new, more inclusive definition of "family," one that reflects the cultural and social diversity of newcomer groups must be adopted in order for the reunification program to fulfill its mandate.
\end{abstract}

\section{Précis}

Cet article examine les implications de l'Après-Multiculturalisme sur l'immigration des groupe familiaux au $\mathrm{Ca}$ nada. Les auteurs développent une argumentation selon laquelle l'objectif de réunification des familles n'est guère facilité par la politique canadienned'immigration. Une définition nouvelle, plus intégrante, de la notion de "famille" reflétant la diversité culturelle et sociale des groupes de nouveaux arrivants doit être adoptée de manière d̀ permettre au programme de réunification de remplir adéquatement son mandat.

\section{Features of Canada's Family Reunification Program}

As a major immigrant-receiving country, Canada advances certain social and economic values by admitting family members as an adjunct to its primary immigration goals of economic and refugee protection (Hathaway 1994). Family-class immigrants are defined as sponsored spouses, fiancé(e)s, dependent children (including adopted children) of Canadian citizens or permanent resi-

Edward Opoku-Dapaah is a PhD candidate and Research Fellow, Centre for Refugee Studies, York University, Toronto.

Michael Lanphier is Director of the Resettlement Unit, Centrefor Refugee Studies, and Professor in the Department of Sociology, York University, Toronto. dents, who have agreed to support their settlement in Canada (CIC 1994, 19). Thus the general family-class category allows Canadian residents to bring to Canada "immediate family" members. Individuals who fall within this category are given priority in the processing of family reunification applications.

Historically, those admitted into Canada under the family-class category have constituted a significant feature of the annual immigrant intake. In 1984,52,084 family immigrants came to Canada, some 58 per cent of total immigration for that year (EIC $1992,10)$. By 1988, family immigration amounted to 66,898 or 43 percent of total immigration. It remained a considerable proportion of total immigration in 1989 and 1990. By 1993, family immigration surpassed all other classes of immigration to Canada. The latter formed 55 per cent of the overall admissions. The 1997 immigration plan anticipates the admission of 58,400 to 66,200 family-class members, which is about one-third of total immigration-a relative decline despite the substantial numbers.

\section{Toward an Inclusive Definition of "Family"}

Even though Canada's family immigration program has remained a significant component of total immigration, the rationale for admission discussed above appears very exclusive. Post-World War II migration waves have not necessarily marked the greatest numbers of the century; yet, they have been by far the most heterogeneous with respect to origin and ethnic background (Simmons 1992).

A majority of contemporary newcomers to Canada originate from nonEuropean sociocultural backgrounds such as Asia, Central America and the Caribbean. Canada has taken official notice and acted in concordance with official pronouncements, the most notable of which has been multiculturalism. Yet developing a rationale for family unification which is inclusive enough for the socially heterogeneous character of Canada, along with the necessary logistics provisions for implementing culturally-sensitive rationale, poses enormous problems for administrative bureaucracy.

Newcomers intending to sponsor relatives from abroad are disadvantaged on several grounds including:

a) the definition of "close family" for immigration purposes, and

b) the standard of proof required to establish family relationship. These difficulties are examined below.

\section{Effect of a Restrictive Definition of Family Class}

Given that the general family-class category recognizes only spouses and unmarried dependent children, the question of who qualifies as family is perhaps one of the most contentious and problematic issues facing newcomers intending to reunite with family members from overseas. In several non-Western communities where contemporary immigrants to Canada originate, the definition of the family encompasses the extended family, such as varying combinations of grandparents, uncles, aunts, nephews and nieces, offspring of brothers and sisters are all considered as part of the close family network (Assimeng 1981).

In addition, individuals in some of these traditional settings may only be related socially or culturally and not biologically. Several immigrant communities in Canada including Ghanaians, Somalis, Cambodians and Ethiopians, cannot comprehend the rationale behind the definition of an "immediate family" which does not include sisters and brothers. Yet, Canada does not allow such flexibility regarding the definition of family. 
Refugees perhaps face the most challenges in family sponsorship. Consider the case of a refugee from a wartorn country such as Somalia, who is also the sole supporter of extended family members. Insistence on a narrow definition of the family class can place the would-be applicant or sponsor in a serious dilemma, and may even jeopardise asylum-seeking abroad by forcing the applicant to abandon his or her kin in an uncertain and precarious social and political situation.

A 1994 National Consultation on the Immigration of Family Members convened by the Department of Citizenship and Immigration also noted these difficulties in managing Canada's family reunification program. With respect to the definition of family members, the consultation argued that the current Immigration Act recognizes only intimate partners in a married, heterosexual union as members of the family class (Hathaway 1994,3). This restrictiveness results in inequality, as other meaningful intimate relationships are excluded from the scope of the family class (ibid., 3 ).

In this light, how relevant is Canada's multiculturalism policy, with respect to the rationale for family reunification? Has the nature of the contemporary social and economic arrangements in Canada inhibited or overtaken the policy?

In any event, difficulties of accommodating definitions at variance with nuclear-dependent family members characteristic of English and Northern European family systems appear nearly intractable (ibid.). Suggestions for combining criteria of family organization, interdependency links among members, for example, with administrative criteria which allow continuation of state control over immigrant admissions, pose administrative hurdles too difficult to surmount at this juncture.

If immigrants from one particular cultural group were to argue successfully for the inclusion of various types of extended family members, for example, it might prove impossible for a government to award the one group admission on the basis of interdependency, while withholding admission to persons of a similar kinship relation from another cultural group who were not so interdependent. In this respect, fostering a universal definition of family for immigration purposes exemplifies the dilemma of forging a single policy from multiple cultural demands. Resultant policy implications for Canada remain ambiguous.

\section{Difficulties in Obtaining Sufficient Proof of Relationship}

The standard of proof of family relationship does not recognise varied forms of symbolic representations of relationships, such as traditional forms of marriages in some cultural contexts. In this case, newcomers from non-European Third-World origins contend that the requirements such as birth certificates, marriage license and other forms of technical and legal proofs are discriminatory. They argue that such requirements impose Western cultural norms on their customary practices. The multiculturalism ideal is cast into a Western European mould.

The custom of documentation does not exist in all societies, and where it does, completeness and quality differ. Unlike Western industrial societies, some immigrants arrive from homelands which do not require identification papers such as birth and marriage certificates or adoption papers to establish authentic family relations. Moreover, in some cultures customary adoptions, though legally and consensually recognized, are not documented. Immigrants from such a background will have difficulty proving that a person is an adopted child and therefore is within the family class. For example, a Cambodian respondent noted:

I have lived with my uncle (mother's brother) and his children since my infancy. He calls me his son. He didn't have to complete any complicated forms or pay any fees towards this. It is fully recognised and accepted that I am his son. Yet, Canadian officers would not understand or accept such an explanation.
Somali newcomers to Canada, for their part, encounter a double-edged problem in proving their relationship to family members to the satisfaction of immigration officials. At the best of times, the country had no tradition of Western-style identification documents which, by and large, were sought only if people intended to travel abroad. Thus it is impossible, for example, for a Somali elder to understand that the proof of relationship with his or her kin hinges on a piece of paper, especially when he or she has never possessed such documentation.

More recently, proof of family ties has required evidence from deoxyribonucleic acid (DNA) testing to establish family sponsorships. This requirement further reinforces governmental insistence of the existing definition of family rather than considering alternative cultural definitions. People from non-Western societies may interpret the DNA test as another bureaucratic strategy to stifle their attempts to reunite with their families.

In this connection, the Human Rights Committee of B'nai Brith Canada, has charged that the DNA test is discriminatory and reflects existing prejudices within the Department of Immigration. The Immigration Minister at the time, Sergio Marchi contended the "DNA test is recommended only as last resort-proof when no other evidence is available." But by May 1995, procedures had become so widely demanded that three Ghanaian-born immigrants reported to a Toronto Star journalist that it appeared from their experience the procedure has become routine for people sponsoring relatives from that country. Thus conditions, both in the home and host countries (Somalia and Canada, respectively), serve to inhibit reunification.

\section{Delivery of Family Reunification Program}

To a large extent, the effectiveness of the family unification program has been contingent upon the existence of mechanisms to counsel and also inform newcomers-the major benefici- 
aries-about the operations of the program. Yet, at the official level, delivery of such services has been beset with serious problems, some logistical and others fiscal-related. As shown by the following discussions, frequent inadequacies in the services from official sources have led potential sponsors to seek assistance from community organizations.

Yet such less-institutionalized sources have also encountered numerous problems of similar nature. As a result, family reunification-an essential aspect of immigrant settlement and social integration-has become organizationally and politically jeopardized. Contemporary social and economic arrangements have overtaken the framework of multiculturalism so that difficulties are experienced with program delivery both in Canada and overseas.

\section{In-Canada Delivery of Family-Class Immigration Program}

As the custodian of immigration policy and enforcement, the CIC has also overseen the delivery of the family reunification program. Regional offices across the country have been mandated to provide information, counselling and delivery of processes integral to the family immigration program. Yet, for a considerable proportion of would-be sponsors such CIC services have become inaccessible for several reasons.

First, difficulties in structuring service delivery inhibit satisfaction of the needs of the diverse groups who constitute today's immigrant and refugee population. Many newcomers, for example, those lacking proficiency in Canada's official languages, find it difficult to approach officials and to communicate their needs. At best translations have been available in a few major languages other than English and French. In addition, people from Third-World countries where the levels of bureaucratic administration are not as advanced or complex as that in Canada tend to feel intimidated when approaching such institutions. In practice, insufficient multicultural "bridges" or intermediate posts are available to permit access to pertinent information about family immigration. It, therefore, has become extremely difficult for authorities to provide counselling and allied services in forms which resonate to the culture of contemporary immigrants to Canada.

In the light of the numerous problems associated with accessing official assistance, would-be sponsors are often compelled to rely on informal sources, such as contacts with kin and compatriots for counselling and assistance regarding family reunification needs. Such information cannot be complete or entirely appropriate because the source persons themselves have experienced similar structural and behavioural discrimination. Therefore, they are not in the most advantageous position to offer advice in gaining access to mainstream information or programming.

\section{Overseas Delivery of Canada's}

\section{Family Immigration Program}

Besides the numerous problems which impair the internal delivery of the family reunification program, the overseas delivery has also met numerous administrative obstacles including limited number of staff, difficulties in locating family members and significant delays in the processing of applications.

A major problem affecting family reunification abroad is the restricted number of Canadian embassies and staff overseas to operate family immigration programs. In some cases access to the Canadian offices is hampered; in other cases, the maldistribution of offices discourages some people to launch family reunification application. There are only three Canadian visa offices, for example, on the entire African continent. Meanwhile over 160,000 Africans have resettled in Canada (five percent of total immigration) since the early 1980 s, many of whom arrived without family members (Census Report 1991).

The maldistribution of overseas services creates undue delays and problems in applications. Most Somalis, for instance, have to deal with the Canadian embassy in Nairobi; however, some have had to travel to Cairo, depending on the geographic region within Somalia (Opoku-Dapaah 1995). Cambodians, for their part, must travel to the single embassy in Thailand. For the latter, Thai visas are needed before they can cross the border. Yet, visas are not always granted to Cambodian applicants. Cambodians in Toronto have noted that their relatives who wanted to enter Thailand for interviews were refused visas.

In sum, management of Canada's family-class immigration has proved extremely difficult partly as a result of the diverse cultural origins of immigrants. Even though Canada's multiculturalism framework preaches tolerance for cultural diversity, it appears nearly impossible to forge a rationale for family-class immigration which can accommodate the varying forms of familial relationships of contemporary immigrants. Thus authorities and newcomers alike contend with a rather narrow, legalistic and Europeanised definition which has often led to the disqualification of relatives whom immigrants deem as close family members.

\section{References}

Assimeng, Max J. 1981. Social Structure of Ghana. Accra: Ghana Publishing Corporation.

Employment and Immigration Canada (EIC). 1992. Managing Immigration: A Framework for The 1990s. Ottawa: EIC.

Hathaway, James C. 1994. Report of the National Consultation on the Immigration of Family Members. Ottawa: CIC.

Opoku-Dapaah, Edward. 1995. "Somali Refugees in Toronto: A Profile." Toronto: Centre for Refugee Studies/York Lanes Press.

Simmons, Alan B. 1992. "New Wave' Immigrants: Origins and Characteristics." In Ethnic Demography: Canadian Immigrant, Racial and Conflict Variations, edited by $\mathrm{S}$. S. Halli et al. Ottawa: Carlton Library Series.

Statistics Canada. 1991. Census Report. ם 